\title{
Identification of Intermetallic Phases in the Alloy AlSi6Cu4
}

\author{
Marko Grzincic ${ }^{1}$, Ivan Lukac ${ }^{2}$ \\ ${ }^{1}$ University J.E. Purkyně, Faculty of Production Technology and Management, Department of Technology and Materi- \\ al Engineering, Pasteurova 3334/7, 40001 Ústí nad Labem, The Czech Republic, E-mail: mgrzincic@yahoo.de \\ ${ }^{2}$ Technical University Košice, Faculty of Metallurgy, Department of Material Science, Letná 9, 04200 Košice, The \\ Slovak Republic, E-mail: ivan.lukac@tuke.sk
}

Presented work focuses on the influence of $\mathrm{Mn}$ and $\mathrm{Fe}$ in different ratios on the structural characteristics of AISi6Cu4 alloys and identification of present intermetallic phases by means of EDX analysis in addition to the light microscopy. The intermetallic phases whatever of type never contribute to strain transfer in matrix and in this view are harmful in the structure. From an economic perspective it is desirable to use cheaper secondary alloys, but to guarantee the required strength properties of the material used for castings, it is needed to control the morphology of intermetalic phases. From the professional literature and practice, relationship between the content of iron and manganese $(\mathrm{Mn} / \mathrm{Fe} \geq 0.7)$ is well known to guarantee the exclusion of intermetallic $\mathrm{Fe}$ in the form/shape of a "Chinese script characters" and not dangerous spindles (needles). It was discovered that this ratio affects the presence of $\mathrm{Mn} / \mathrm{Fe}$ also in the intermetallic phases. With increasing Sr content in the experiments conducted, the percentage of $\mathrm{Mn} / \mathrm{Fe}$ ratio in intermetallic phase in form of "Chinese script characters" reduces. It was found that under certain circumstances, also the ratio $\mathrm{Mn} / \mathrm{Fe}=0.7$ does not guarantee the presence of intermetallic Fe phases only in the form of "Chinese script characters" in areas of highest stress of castings, i.e. on the castings of cylinder heads in the area of combustion chambers.

Keywords: Casting alloy, AlSi6Cu4 (A319), ratio Mn/Fe, intermetallic phase, EDX analysis

\section{References}

[1] HWANG, J.Y., DOTY, H.W., KAUFMAN, M.J. (2008): The effects of Mn additions on the microstructure and mechanical properties of Al-Si-Cu casting alloys. In: Materials Science and Engineering, A 488, pp. $496-504$.

[2] FEGYVERNEKI, G. (2009): Solidification circumstances in case of Al-Si cylinder-head castings. World Technical Forum, 1st - 3rd June 2009, Brno.

[3] VOORT, G. F. (1999): Metallography: Principles and Practice,pp. 102-108, ASM International Materials Park, Ohio.

[4] ASHBY, M. F. (1993): Engineering Materials, pp. 88-91, Pergamon Press, Oxford.

[5] KOLAŠEV, B. A. (2001): Metallovedenie i termičeskaja obrabotka, cvetnych metalov i splavov, pp. 37-47, MISSIS, Moskva.

[6] ASM Handbook (1987), Fractography, Vol. 12, pp. 17-31, ASM International, Ohio.

[7] ASM Handbook, Vol. 2 (1992), Properties and Selection Nonferrous Alloys and Special-Purpose Materials, pp. 215-244, ASM International, Ohio.

[8] ASHBY, M.F., JONES, D.R.H. (2009): Engineering Materials, Vol. 3, Materials Failure Analysis, pp. 115-133, Pergamon Press, Oxford.

[9] WANG, L. et al (1995): Aluminium Die Casting Alloys, In: International Materials Reviews, No. 6, pp. $221-228$.

[10] BARLOW, I.C. et al (2008): The role of silicon in the formation of the $\sigma$ phase in Al-Cu-Mg alloys. In: Journal of Materials Science, No. 3, pp. 1413-1421.

[11] LASA, L., RODRIGUEZ-IBABE, J.M. (2004): Evolution of the main intermetallic phases in Al-Si-Cu-Mg casting alloys during solution treatment. In: Journal of Materials Science, Vol. 39, Issue 4, pp. 1343-1355.

[12] BER, L.B. (2000): Accelerated artificial ageing regimes of commercial aluminum alloys. I. Al-Cu-Mg alloys. In: Materials Science and Engineering, No. 3, pp. 83-91.

[13] LIU, K., CAO, X., CHEN, X.-G. (2012): Precipitation of iron-rich intermetallic phases in Al-4.6Cu-0.5Fe-0.5Mn cast alloy. In: Journal of Materials Science, Vol. 47, Issue 10, pp. 4290-4298.

[14] ASTM E 1181-87, Standard Testing Procedures for the Description of the Dual Grain Size, pp. 1-35.

[15] ASTM E 112-96, Standard Testing Procedures for Determining the Average Grain Size, pp. 1-32. 
[16] LUKÁČ, I. et al (1998): Metallography '98, Proceedings of the 10th International Symposium on Metallography, April, High Tatras.

[17] BOLIBRUCHOVÁ, D., RICHTÁRECH, L. (2013): Effect of adding iron to the AlSi7Mg0.3 (EN AC 42100 , A356) alloy. In: Manufacturing Technology, Vol. 13, No. 3, pp. 276-281.

[18] BOLIBRUCHOVÁ, D., BRŮNA, M. (2013): Influencing the crystallization of secondary alloy A1Si6Cu4 with strontium. In: Manufacturing Technology, Vol. 13, No. 1, pp. 7-14.

\section{Paper number: M201430}

Copyright (C) 2014. Published by Manufacturing Technology. All rights reserved. 